\title{
Bioassay and molecular monitoring of insecticide resistance status in Aedes albopictus populations from Greece, to support evidence-based vector control
}

Sofia Balaska ${ }^{1,2}$, Emmanouil A. Fotakis ${ }^{1}$, Ilias Kioulos ${ }^{1}$, Linda Grigoraki ${ }^{3}$, Spyridoula Mpellou ${ }^{4}$, Alexandra Chaskopoulou ${ }^{5}$ and John Vontas ${ }^{1,2^{*}}$

\begin{abstract}
Background: Aedes albopictus has a well-established presence in southern European countries, associated with recent disease outbreaks (e.g. chikungunya). Development of insecticide resistance in the vector is a major concern as its control mainly relies on the use of biocides. Data on the species' resistance status are essential for efficient and sustainable control. To date the insecticide resistance status of Ae. albopictus populations from Greece against major insecticides used in vector control remains largely unknown.
\end{abstract}

Methods: We investigated the insecticide resistance status of 19 Ae. albopictus populations from 11 regions of Greece. Bioassays were performed against diflubenzuron (DFB), Bacillus thuringiensis var. israelensis (Bti), deltamethrin and malathion. Known insecticide resistance loci were molecularly analysed, i.e. voltage-gated sodium channel (VGSC) mutations associated with pyrethroid resistance; presence and frequency of carboxylesterases 3 (CCEae3a) and 6 (CCEae6a) gene amplification associated with organophosphate (OP) resistance and; chitin synthase-1 (CHS-1) for the possible presence of DFB resistance mutations.

Results: Bioassays showed full susceptibility to DFB, Bti and deltamethrin, but resistance against the OP malathion (range of mortality: 55.30-91.40\%). VGSC analysis revealed a widespread distribution of the mutations F1534C (in all populations, with allelic frequencies between 6.6-68.3\%), and I1532T (in 6 populations; allelic frequencies below $22.70 \%$ ), but absence of $\mathrm{V} 1016 \mathrm{G}$. CCE gene amplifications were recorded in 8 out of 11 populations (overall frequency: 33\%). Co-presence of the F1534C mutation and CCEae3a amplification was reported in 39 of the 156 samples analysed by both assays. No mutations at the CHS-1 11043 locus were detected.

Conclusions: The results indicate: (i) the suitability of larvicides DFB and Bti for Ae. albopictus control in Greece; (ii) possible incipient pyrethroid resistance due to the presence of $k d r$ mutations; and (iii) possible reduced efficacy of OPs, in a scenario of re-introducing them for vector control. The study highlights the need for systematic resistance monitoring for developing and implementing appropriate evidence-based control programmes.

Keywords: Diagnostic, Bioassay, Arbovirus, Vector control, Mosquito tiger, Insecticide resistance, kdr, Bti, Gene amplification

\footnotetext{
*Correspondence: vontas@imbb.forth.gr

${ }^{2}$ Institute of Molecular Biology and Biotechnology, Foundation for Research and Technology Hellas, Heraklion, Greece

Full list of author information is available at the end of the article
}

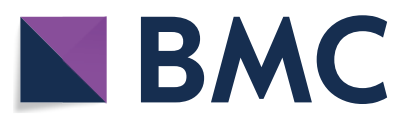

(c) The Author(s) 2020. This article is licensed under a Creative Commons Attribution 4.0 International License, which permits use, sharing, adaptation, distribution and reproduction in any medium or format, as long as you give appropriate credit to the original author(s) and the source, provide a link to the Creative Commons licence, and indicate if changes were made. The images or other third party material in this article are included in the article's Creative Commons licence, unless indicated otherwise in a credit line to the material. If material is not included in the article's Creative Commons licence and your intended use is not permitted by statutory regulation or exceeds the permitted use, you will need to obtain permission directly from the copyright holder. To view a copy of this licence, visit http://creativeco mmons.org/licenses/by/4.0/. The Creative Commons Public Domain Dedication waiver (http://creativecommons.org/publicdomain/ zero/1.0/) applies to the data made available in this article, unless otherwise stated in a credit line to the data. 


\section{Introduction}

In the last two decades southern European countries have suffered from a number of vector-borne diseases (VBDs), such as chikungunya (CHIKV), dengue (DENV) and West Nile virus (WNV) outbreaks [1,2]. This has been attributed to several factors including the introduction and establishment of invasive vector species, associated with the ongoing environmental and climate change and the globalization of human activities [3].

Aedes albopictus is an important vector and invasive mosquito species. Originating from the tropical and subtropical regions of southern Asia, it currently displays a worldwide distribution [4] facilitated by its ecological plasticity, competitive behavior and egg diapause/dormancy behaviour during the winter period [5]. Aedes albopictus was first recorded in Europe in 1979 [6] and to date displays a wide-spread distribution in the Mediterranean region while also reported in northern European countries [7]. Being a competent vector of more than 22 arboviruses, including CHIKV and DENV [8], Ae. albopictus constitutes a major public health threat. Its presence in Europe has been associated with the local transmission of CHIKV in Italy (2007 and 2017) and southeastern France (2010 and 2014) and of DENV in France (2010, 2013-2015), Spain (2014-2016) and Croatia (2010) [1]. Furthermore, since 2016 more than 2400 imported Zika cases have been reported in Europe [9, 10], which in conjunction with the known distribution of Ae. albopictus and Zika vectorial capacity raises concerns for potential autochthonous Zika transmission [11].

Aedes albopictus has also been reported in Greece [12], a country witnessing consecutive WNV outbreaks since 2010, with the largest outbreak in 2018 resulting in a total of 316 human cases and 50 fatalities [13]. Although Culex pipiens has been implicated as the primary WNV vector in Greece [14], Ae. albopictus could potentially have a role in disease transmission, as a secondary vector $[5,15]$. Apart from a major public health concern, Ae. albopictus causes an important biting nuisance problem, negatively affecting the quality of life and potentially acting as a discouraging factor for the tourist economy [16].

The prevention of mosquito-borne diseases (MBDs) relies to a great extent on vector control [17] and the utilization of synthetic insecticides [18]. In Europe, pyrethroids (e.g. permethrin, deltamethrin and alpha-cypermethrin) and the larvicides diflubenzuron (DFB) and pyriproxyfen are the main insecticides used to control adult and immature stage Aedes mosquitoes, respectively $[18,19]$. In Greece, applications of Bacillus thuringiensis israelensis (Bti) and of the insect growth regulator (IGR) DFB compose the majority of the vector control interventions implemented in large-scale (regional level) control programmes [20]. Pyrethroid insecticides, including type I (non-alpha-cyano group, such as permethrin) and type II (alpha-cyano group, such as deltamethrin and alpha-cypermethrin) formulations, are registered and used in professional vector control programmes and for personal protection/household level applications [21]. A major issue associated with the intensive use of a limited number of insecticides in mosquito and agricultural pest control is the development of insecticide resistance [18]. Insecticide resistance has been reported in Ae. albopictus, yet a big knowledge gap remains in regards to the susceptibility status, geographical distribution, frequency and co-occurrence of resistance traits and underlying mechanisms in the vector populations. Bioassay experiments have recorded resistance to several insecticides including pyrethroids, DDT, temephos, malathion, etc. mainly in rural and urban central and southern Asian populations (e.g. from China, Thailand, Singapore and India), while only sporadic cases of resistance have been reported in Europe, America and western Africa [18].

The two insecticide resistance mechanisms reported so far in Aedes mosquitoes are (i) target-site resistance, involving mutations at the insecticide's target site of action and (ii) metabolic detoxification, obtained through overexpression or conformational changes of enzymes involved in the metabolism of the insecticide $[18,22]$. To date, five mutations in two loci of the voltage-gated sodium channel (VGSC) gene; V1016G (valine to glycine), I1532T (isoleucine to threonine) and F1534C/L/S (phenylalanine to cysteine/leucine/serine), have been reported in Ae. albopictus populations from central and southeastern Asia, European Mediterranean countries, the USA and Brazil [18].

The involvement of these five mutations in insecticide resistance has been further examined by expressing the mutated VGSC channels in Xenopus eggs and investigating how their electrophysiological properties are affected in the presence of insecticides. All three mutations at position F1534 (F1534C/L and S), as well as the I1532T mutation have been shown to significantly reduce the channel's sensitivity to type I but not to type II pyrethroids [23, 24]. The V1016G mutation also reduces the channel's sensitivity mainly to permethrin and slightly to deltamethrin [23]. However, a synergistic effect has been reported in the presence of the triple mutant $\mathrm{V} 1016 \mathrm{G}+\mathrm{F} 1534 \mathrm{C}+\mathrm{S} 989 \mathrm{P}$ (a third mutation identified in Ae. aegypti populations), which substantially reduced sensitivity to both permethrin and deltamethrin [25].

Pyrethroid resistance has also been correlated to CYP6P12 over-expression conferring increased metabolic detoxification [26]. Metabolic resistance to the larvicide temephos (OP) has been functionally associated with the upregulation of carboxylesterases CCEae3a and CCEae6a, due to gene amplification [27]. Aedes 
albopictus populations from Greece and Florida (USA) have been found to carry this CCEae3a gene amplification or the CCEae3a-CCEae6a co-amplification [28]. Regarding alternative insecticides, such as IGRs or Bti, no genotypic resistance data have been reported for Aedes mosquitoes, but three point mutations I1043M/ $\mathrm{L} / \mathrm{F}$ in the chitin synthase-1 (CHS-1) gene were recently identified in $C x$. pipiens mosquitoes, conferring very high levels of resistance to the larvicide DFB [29-31].

The re-appearance of VBDs in Europe, the widespread distribution of Ae. albopictus in southern Europe, the sporadic information on the vectors' insecticide resistance status and the need for evidence-based mosquito control programmes acting in advance of disease outbreaks, make the monitoring and analysis of the Ae. albopictus insecticide resistance traits a necessity [32]. Here, we analysed the insecticide resistance status in a number of Ae. albopictus populations from Greece, using bioassays and molecular genotyping assays targeting known resistance markers.

\section{Methods}

Study localities, sample collections and mosquito handling Adult and immature stage Ae. albopictus mosquitoes were collected during the summer of 2017, 2018 and 2019 , in a total of 19 urban and peri-urban localities in Greece, in the regions of Thessaloniki [33] and Rodopi (northern Greece), Attica and Argolida (central Greece), the Island of Chios (north-eastern Aegean Islands complex) [33], Patras and Kalamata (western Greece), the Island of Kefalonia (Ionian Islands complex) and Crete (Chania, Rethymno and Heraklion - southern Greece) (Fig.1, Table 1). The localities we selected to include in the analysis were chosen based on: their geographical location (in order to cover a large geographical area of Greece), the history of insecticide applications, previous insecticide resistance findings in other mosquito species and the availability of Ae. albopictus samples (mosquito collections/surveillance programmes).

Samples were collected every 2 weeks over a period of 1 or 2 months; a total of 3 to 7 collection events were conducted for each locality. Adult specimens were collected with mouth aspiration catches and CDC-light traps baited with dry ice. Larvae were sampled from natural and man-made/artificial containers with dipping collections and eggs were collected with oviposition traps (black plastic cups of $8 \mathrm{~cm}$ top diameter, $5 \mathrm{~cm}$ bottom diameter and $13 \mathrm{~cm}$ height; half covered with tap or rain water, with 2 wooden tongue depressors as oviposition substrate), baited with hay infusion and placed outdoors, amongst low vegetation, away from direct sunlight. Both larvae and eggs were collected from at least five different sites within each locality in order to avoid family bias and minimize the probability of including isofemale mosquitoes in the molecular analyses.

Following ovitrap collections, eggs were reared to adults in standard insectary conditions (temperature $27 \pm 2{ }^{\circ} \mathrm{C}$ and relative humidity $70-80 \%$ ), identified morphologically to species [34] and stored individually in absolute ethanol at $4{ }^{\circ} \mathrm{C}$ for the subsequent molecular analysis. A subgroup of eggs from the Aghios Stefanos locality (region of Attica; ovitrap collections from Aghios Stefanos were conducted in 2019, while samples analysed molecularly were collected in 2018), Kefalonia, Patras and Heraklion were reared to larvae or adults to use for susceptibility bioassays, as described below.

\section{Genomic DNA extraction and molecular identification of mosquito species}

Genomic DNA (gDNA) was extracted from individual larvae or adult mosquitoes and from pools of eggs (10 eggs per pool per locality; 3 localities), using DNAzol reagent (Invitrogen, Carlsbad, CA, USA) according to manufacturer's instructions.

Species identification was based on the PCR amplification (KAPA Taq PCR Kit; KAPA Biosystems) of the nuclear ribosomal gene spacer ITS2, following an assay that discriminates between Ae. albopictus, Ae. cretinus and Ae. aegypti, by generating PCR products of $509 \mathrm{bp}$, $385 \mathrm{bp}$ and $324 \mathrm{bp}$ in length, respectively, as described in Patsoula et al. [35]; the $25 \mu \mathrm{l}$ PCR reaction contained 1 $\mu \mathrm{l}$ gDNA, $2.5 \mu \mathrm{l}$ of $10 \times$ DNA polymerase buffer, $2 \mathrm{mM}$ $\mathrm{MgCl}_{2}, 0.4 \mu \mathrm{M}$ of each primer (primers 5.8S and 28S [36]; Additional file 1: Table S1), $0.4 \mu \mathrm{M}$ of dNTPs and $1.5 \mathrm{U}$ of Taq polymerase. The applied thermal protocol was the following: initial denaturation at $94{ }^{\circ} \mathrm{C}$ for $5 \mathrm{~min}, 40$ cycles $\times$ [denaturation at $94{ }^{\circ} \mathrm{C}$ for $1 \mathrm{~min}$, primer annealing at $52{ }^{\circ} \mathrm{C}$ for $1 \mathrm{~min}$, primer extension at $72{ }^{\circ} \mathrm{C}$ for 1 $\mathrm{min}$ ] and a final extension step at $72{ }^{\circ} \mathrm{C}$ for $10 \mathrm{~min}$. The PCR products were electrophoresed on a $1.5 \% \mathrm{w} / \mathrm{v}$ agarose gel containing ethidium bromide.

\section{Insecticide susceptibility bioassays Larval bioassays}

Following the WHO guidelines for laboratory and field testing of mosquito larvicides [37], we examined the susceptibility of Ae. albopictus populations against two larvicides; the bacterial larvicide Bti (VectoBac12AS, Valent BioSciences LLC, Illinois, USA; 1200 ITU (international toxic units) $/ \mathrm{mg} ; 11.61 \% \mathrm{w} / \mathrm{v}$ ) and the insect growth regulator DFB (DU-DIM 15SC, Arysta LifeScience, Amsterdam, The Netherlands; $15 \% \mathrm{w} / \mathrm{v})$. Both insecticides were diluted in distilled water. Bioassays were performed using Ae. albopictus third-early fourth-instar larvae $\left(\mathrm{F}_{0}-\mathrm{F}_{1}\right.$ generation), reared under standard insectary conditions (temperature $27 \pm 2{ }^{\circ} \mathrm{C}$ and relative humidity $70-80 \%$ ). 
Fifteen to 20 larvae were placed in $99 \mathrm{ml}$ water, to which $1 \mathrm{ml}$ of the insecticide solution was added. Control bioassays contained $100 \mathrm{ml}$ water. A range of 5 to 9 concentrations were tested for each insecticide (Bti: 0.008-0.500 $\mathrm{mg} / \mathrm{l}$; DFB: $0.0004-0.0200 \mathrm{mg} / \mathrm{l}$ ) in order to define a mortality range between 10 and $95 \%$ and determine the $\mathrm{LC}_{50}$ and $\mathrm{LC}_{95}$ values. Three to 4 replicates were tested for each concentration. Larval mortality was recorded after the WHO recommended exposure time for each insecticide. Moribund larvae were counted as dead [37]. $\mathrm{LC}_{50}$ and $\mathrm{LC}_{95}$ values were estimated using the log-probit analysis Polo Plus 2.0 LeOra software (LeOra Software
LLC, Parma, USA). Results were compared to the values reported for susceptible-laboratory Ae. albopictus strains in other studies [38-40].

\section{Adult bioassays}

Three to five day-old, non-blood fed female mosquitoes $\left(\mathrm{F}_{1}-\mathrm{F}_{2}\right.$ generation) were subjected to insecticide susceptibility tests against deltamethrin and malathion, following the CDC bottle bioassay guidelines [41]. A Malaysian Ae. albopictus susceptible laboratory strain was included [42]. Both insecticides were purchased as technical grade material (PESTANAL $^{\circledR}$ analytical standard;

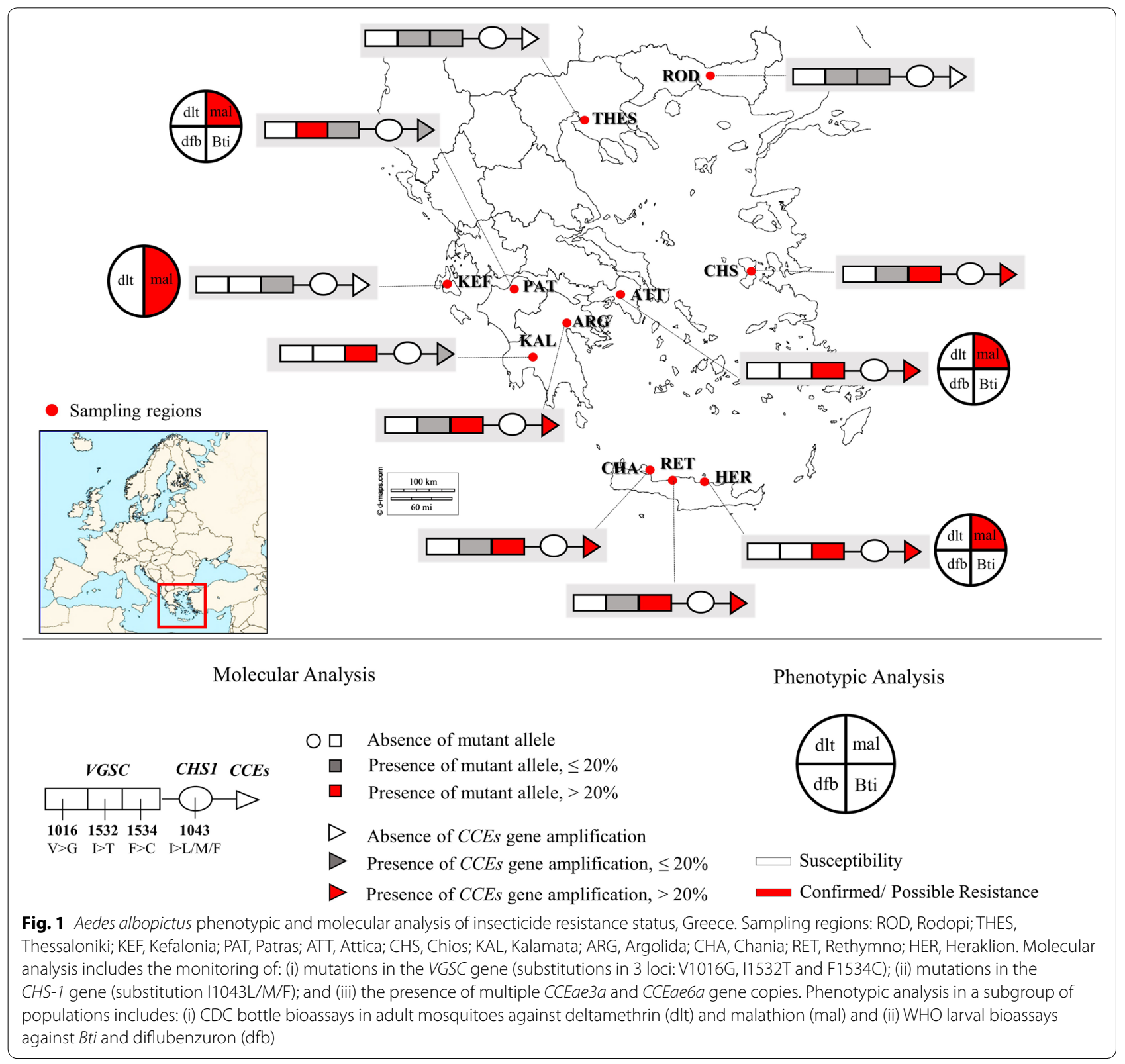


Table 1 Aedes species composition per study site

\begin{tabular}{|c|c|c|c|c|c|}
\hline Region & Locality & Collection date & $n$ & Ae. albopictus & Ae. cretinus \\
\hline Rodopi & lasmos & August 2018 & 14 & 14 & 0 \\
\hline \multirow[t]{3}{*}{ Thessaloniki } & Thermi-Litsa ${ }^{\mathrm{b}}$ & September 2018 & 30 & 30 & 0 \\
\hline & Refugee camp Diavatac & June 2017 & $10^{\mathrm{a}}$ & $10^{\mathrm{a}}$ & 0 \\
\hline & Refugee camp Lagkadikiac & June 2017 & $18^{\mathrm{a}}$ & $18^{\mathrm{a}}$ & 0 \\
\hline Chios & Refugee camp Soudac & June 2017 & $23^{a}$ & $23^{\mathrm{a}}$ & 0 \\
\hline \multirow[t]{4}{*}{ Attica } & Aigaleo & August-September 2018 & 24 & 24 & 0 \\
\hline & Filothei & August-September 2018 & 14 & 14 & 0 \\
\hline & Aghios Stefanos & October 2018 & 36 & 36 & 0 \\
\hline & Aghios Eleftherios & October 2018 & 24 & 24 & 0 \\
\hline Kefalonia & Paliki & November 2019 & 45 & 45 & 0 \\
\hline Patras & Rio & September 2019 & 33 & 33 & 0 \\
\hline \multirow[t]{2}{*}{ Argolida } & Aghia Triada & August-September 2018 & 8 & 8 & 0 \\
\hline & Kilada & September 2018 & 57 & 57 & 0 \\
\hline Kalamata & Town & August 2018 & 7 & 7 & 0 \\
\hline \multirow[t]{2}{*}{ Chania } & Town & September-October 2018 & 36 & 27 & 9 \\
\hline & Souda & August-October 2018 & 33 & 30 & 3 \\
\hline \multirow[t]{2}{*}{ Rethymno } & Town & August 2018 & 38 & 38 & 0 \\
\hline & Panormos & August-September 2018 & 18 & 18 & 0 \\
\hline Heraklion & Giofyro & June-July 2019 & 44 & 44 & 0 \\
\hline
\end{tabular}

a Includes 10 eggs analyzed as a pool

b Thermi-Litsa is an organic farming locality

c Samples from Diavata, Lagkadikia and Souda refugee camps were collected and analysed in Fotakis et al. [33]

Abbreviation: $n$, total number of specimens analyzed per sampling region for species identification

Sigma-Aldrich, Darmstadt, Germany). Insecticide stock solutions were prepared in acetone and Wheaton bottles were cleaned and coated as described in the CDC guidelines. The diagnostic dose of the insecticide under evaluation was used: deltamethrin at $10 \mu \mathrm{g} / \mathrm{bottle}$ and malathion at $50 \mu \mathrm{g} /$ bottle. Tests were performed using 20-25 mosquitoes per bottle. Four insecticide treated replicate bottles and at least one control bottle (coated with acetone only) were used in each experiment set. The diagnostic time for both insecticides tested was 30 min [41]. Alive and dead mosquitoes in each bottle were recorded at time intervals of 5-15 min. The insecticide susceptibility status was determined by the mortality rate at the diagnostic time, according to CDC recommendations: $98-100 \%$ mortality at the diagnostic time indicates susceptibility; $80-97 \%$ suggests the possibility of resistance that requires further confirmation; and mortality $<80 \%$ denotes resistance. In cases where mortality (between 3-5\%) was recorded in the control bottles at the $2 \mathrm{~h}$ timepoint, mortality data were corrected using Abbott's formula.

\section{Genotyping of target site resistance mutations Detection of knock-down resistance $(k d r)$ mutations in the VGSC gene}

The VGSC domain II was investigated for the presence of the V1016G mutation and domain III for mutations $\mathrm{I} 1532 \mathrm{~T}$ and $\mathrm{F} 1534 \mathrm{~L} / \mathrm{S} / \mathrm{C}$ via $\mathrm{PCR}$ and product sequencing.

The PCR (KAPA Taq PCR Kit) for domain II was carried out in $25 \mu \mathrm{l}$ containing $1.5 \mu \mathrm{l}$ of mixed gDNA extracted individually from 5-8 Ae. albopictus samples of the same locality, $2.5 \mu \mathrm{l}$ of $10 \times$ DNA polymerase buffer, $0.4 \mu \mathrm{M}$ of each primer (primers kdr2F and kdr2R; Additional file 1: Table S1), $0.4 \mu \mathrm{M}$ of dNTPs and $1.5 \mathrm{U}$ of Taq polymerase. The PCR thermal conditions were: initial denaturation at $95{ }^{\circ} \mathrm{C}$ for $5 \mathrm{~min}, 40$ cycles $\times$ [denaturation at $94{ }^{\circ} \mathrm{C}$ for $30 \mathrm{~s}$, primer annealing at $55^{\circ} \mathrm{C}$ for $30 \mathrm{~s}$, primer extension at $72{ }^{\circ} \mathrm{C}$ for $1 \mathrm{~min}$ ] and a final extension step at $72{ }^{\circ} \mathrm{C}$ for $5 \mathrm{~min}$. A small amount of the PCR products $(5 \mu \mathrm{l})$ was electrophoresed on a $1 \% \mathrm{w} / \mathrm{v}$ agarose gel to verify the presence of the correct size amplicon (500 bp), and the remaining amount was purified using the Nucleospin PCR \& Gel Clean-Up Kit (Macherey Nagel) and sequenced using the Sanger method (CeMIA S.A., Larissa, Greece) with primer kdr2F. Sequences were 
analysed using the sequence alignment editor BioEdit 7.2.5 (https://bioedit.software.informer.com/7.2/).

The PCR for domain III was carried out in $25 \mu \mathrm{l}$ containing $1.5 \mu \mathrm{l}$ of gDNA from Ae. albopictus individuals, $2.5 \mu \mathrm{l}$ of $10 \times$ DNA polymerase buffer, $2 \mathrm{mM} \mathrm{MgCl} 2,0.3$ $\mu \mathrm{M}$ of each primer (primersaegSCF7 and aegSCR7 [43]; Additional file 1: Table S1), $0.4 \mathrm{uM}$ of dNTPs and $1.5 \mathrm{U}$ of Taq polymerase. The thermal conditions of the PCR were: initial denaturation at $95^{\circ} \mathrm{C}$ for $5 \mathrm{~min}, 40$ cycles $\times$ [denaturation at $94^{\circ} \mathrm{C}$ for $30 \mathrm{~s}$, primer annealing at $57^{\circ} \mathrm{C}$ for 30 s, primer extension at $72{ }^{\circ} \mathrm{C}$ for $1 \mathrm{~min}$ ] and a final extension step at $72{ }^{\circ} \mathrm{C}$ for $5 \mathrm{~min}$. The products were electrophoresed on a $1 \% \mathrm{w} / \mathrm{v}$ agarose gel and the specific $740 \mathrm{bp}$ band was gel extracted and purified using the Nucleospin PCR \& Gel Clean-Up Kit (Macherey Nagel, Dueren, Germany) and sequenced using the Sanger method (CeMIA S.A.) with primer aegSCR8. Sequences were analysed using the sequence alignment editor BioEdit 7.2.5.

\section{Analysis of the CHS-1 1043 locus}

Analysis of the CHS-1 I1043 locus, to identify possible conserved DFB resistance mutations found in other species [29,31], was performed in pools of mixed gDNA extracted individually from 5-8 Ae. albopictus samples of the same locality. Available Ae. albopictus DNA samples from other countries [28] were included in the analysis and genotyped individually. A 350-bp fragment of the CHS-1 gene, spanning the 1043 locus (numbering based on Musca domestica genomic sequence) was amplified in a $25 \mu \mathrm{l}$ PCR (KAPA Taq PCR Kit) containing $1.5 \mu \mathrm{l}$ DNA, $2.5 \mu \mathrm{l}$ of $10 \times$ DNA polymerase buffer, $0.4 \mu \mathrm{M}$ of each primer (primers kkv F3 and kkv R3; Additional file 1: Table S1), $0.4 \mu \mathrm{M}$ of dNTPs and $1.5 \mathrm{U}$ of Taq polymerase. The thermal conditions were: initial denaturation at $95{ }^{\circ} \mathrm{C}$ for $5 \mathrm{~min}, 40$ cycles $\times$ [denaturation at $94{ }^{\circ} \mathrm{C}$ for $30 \mathrm{~s}$, primer annealing at $55{ }^{\circ} \mathrm{C}$ for $30 \mathrm{~s}$, primer extension at $72{ }^{\circ} \mathrm{C}$ for 1 min] and final extension step at $72{ }^{\circ} \mathrm{C}$ for $10 \mathrm{~min}$. A small amount of the PCR products was electrophoresed on a $1.5 \% \mathrm{w} / \mathrm{v}$ agarose gel containing ethidium bromide to verify amplification. The remaining amount of the PCR products was purified using the Nucleospin PCR \& Gel Clean-Up Kit (Macherey Nagel) and sequenced using the Sanger method (CeMIA S.A.) with the kkv F3 primer. Sequences were analysed using the sequence alignment editor BioEdit 7.2.5.

\section{Metabolic resistance: detection of esterase gene amplification}

CCEae3a and CCEae6a gene copy numbers were determined using quantitative real-time PCR on individual Ae. albopictus specimens. Amplification reactions at a $10 \mu$ l final volume were performed on a StepOnePlus Real-Time PCR System (Applied Biosystems, California, USA) containing $0.5 \mu \mathrm{l}$ of gDNA, $0.2 \mu \mathrm{M}$ of each primer (CCEae3aF, CCEae3aR, CCEae6aR and CCEEae6aF; Grigoraki et al. [28]; Additional file 1: Table S1) and SYBR Select Master Mix (Applied Biosystems, Thermo Fisher Scientific, California, USA). Histone 3 (GenBank: XM_019687528.2) was used as a reference gene for normalization (primers His3 TaqF and His3 TaqR; Additional file 1: Table S1). The thermal parameters were: $50{ }^{\circ} \mathrm{C}$ for $2 \mathrm{~min} ; 95^{\circ} \mathrm{C}$ for $2 \mathrm{~min}$, and 40 cycles $\times\left[95{ }^{\circ} \mathrm{C}\right.$ for $3 \mathrm{~s}, 60^{\circ} \mathrm{C}$ for $30 \mathrm{~s}$ ]. Melting curves were performed for reference and target genes to verify the presence of a unique specific PCR product, which was checked on a $1 \%$ w/v agarose gel. A no-template control was included to detect possible contamination. Two replicates per sample were included. CCEae3a and CCEae6a gene copy numbers were estimated relatively to a temephos susceptible Ae. albopictus laboratory strain from Greece.

\section{Results}

Molecular identification of mosquito species

A total of 482 individual mosquitoes (larvae and adults) and 30 eggs (in pools) were identified to species by PCR discrimination of the ITS2 genomic sequence length; 97.6\% of the samples were identified as Ae. albopictus, while only 12 specimens, all from Chania, Crete, were identified as Ae. cretinus (corresponding to $17.4 \%$ of the Chania population) (Table 1). No Ae. aegypti mosquitoes were recorded.

\section{Insecticide susceptibility bioassays Larval bioassays}

Aedes albopictus populations from Aghios StefanosAttica (ATT), Patras and Heraklion, were tested for Bti resistance and found to be susceptible (Fig. 1). The calculated $\mathrm{LC}_{50}$ values were below $0.20 \mathrm{mg} / \mathrm{l}$ (corresponding to less than $0.240 \mathrm{ITU} / \mathrm{ml}$ ) for all populations (Table 2), which is less than the $\mathrm{LC}_{50}$ values reported for susceptible Ae. albopictus laboratory strains in other studies. Indicatively, in $\mathrm{Li}$ et al. [39] and Su et al. [40], the reported $\mathrm{LC}_{50}$ values of the control susceptible strains were $0.036 \mathrm{mg} / \mathrm{l}$ and $0.044 \mathrm{mg} / \mathrm{l}$, respectively (Bti formulation $7000 \mathrm{ITU} /$ $\mathrm{mg})$.

All three populations were also tested for diflubenzuron resistance and showed mortality of $100 \%$ in DFB doses below $0.02 \mathrm{mg} / \mathrm{l}$. This is remarkably lower than the recommended field doses (DU-DIM 15SC: 0.32-0.63 $\mathrm{mg} / \mathrm{l})$, the recommended WHO dosage of DFB in potable water containers $(0.25 \mathrm{mg} / \mathrm{l})$ [44], as well as the emergence inhibition dose $\left(\mathrm{EI}_{50}\right.$ of $\left.0.376 \mathrm{mg} / \mathrm{l}\right)$ previously reported for susceptible Ae. albopictus field strains [38]. 


\section{Adult bioassays}

Aedes albopictus populations from Aghios StefanosAttica (ATT), Kefalonia, Patras and Heraklion were susceptible to deltamethrin (Fig. 1), as the mortality recorded at the $30 \mathrm{~min}$ diagnostic time was $100 \%$ (Table 3, Additional file 2: Figure S1). On the other hand, populations from Aghios Stefanos-Attica (ATT), Kefalonia and Heraklion, were resistant to malathion, displaying approximately $55 \%$ mortality at the diagnostic time (30 $\mathrm{min}$ ), while the Patras population had a mortality of $91.4 \%$, indicating possible resistance (Table 3, Additional file 2: Figure S1).

\section{Genotyping of target site resistance mutations VGSC: $k d$ mutations at positions V1016, 11532 and F1534}

As the V1016G $k d r$ mutation has never been recorded in Greece, pooled gDNA was used as a template for $V G S C$ domain II amplification. Genotyping of the VGSC domain II was performed for a total of 323 larvae/adult mosquitoes (in 2-10 pools per region, depending on the number of specimens analysed per locality; 5-8 individuals per locality per pool) and 20 eggs (in pools of 10 per locality). The small number of specimens included per pool would enable the detection of any resistance allele upon sequencing. The wild type allele V1016 (codon GTA) was recorded in all cases (Fig. 1, Table 4).

For the detection of mutations $\mathrm{I} 1532 \mathrm{~T}$ and $\mathrm{F} 1534 \mathrm{C} / \mathrm{L} / \mathrm{S}$ in the VGSC domain III, 319 individuals were genotyped. For the first time in Greece, the I1532T mutation was detected in 6 out of the 11 surveyed regions. Particularly, 23 genotyped specimens from Rodopi, Thessaloniki, Patras, Argolida, Rethymno and Chania were found to have this substitution, mostly in heterozygosis (genotype $1532 \mathrm{I} / 1532 \mathrm{~T}$ ). In the majority of the above-mentioned regions, the mutant allele $1532 \mathrm{~T}$ frequency was low, varying from 1.7 to $6.5 \%$ (Fig. 1). The highest frequency was observed in Patras (22.7\%; the only 2 homozygotes $1532 \mathrm{~T} / 1532 \mathrm{~T}$ were reported there) (Table 4).

The F1534C mutation was found in all regions. The regions with the highest $1534 \mathrm{C}$ allele frequency were Attica (68.3\%), Argolida (45.2\%), Rethymno (48.3\%), Heraklion (44.3\%) and Chania (29\%), all located in central and southern Greece (we excluded Kalamata results due to the small number of specimens collected and analysed). In contrast, regions from northern Greece (Rodopi and Thessaloniki) and western Greece (Patras and Kefalonia) displayed lower $1534 \mathrm{C}$ allele frequencies, ranging between 6.6 and 16.7\% (Fig. 1). The F1534C mutation appeared mainly in heterozygosis, with the exception of Attica, where more than half of the genotyped specimens were homozygous for the mutation (genotype 1543C/1534C) (Table 4). Only two individuals (sampled from Argolida and Patra) harboured both mutations, I1532T and F1534C, in heterozygosis (genotype 1532I/1532T; 1534F/1534C).

\section{Chitin synthase (CHS-1): mutations at position I1043}

The CHS-1 genomic sequence of 325 Ae. albopictus mosquitoes (in 2-10 pools per region, depending on the number of specimens analysed per locality; 5-8 individuals per locality per pool) and a total of 20 eggs (in pools of 10 per locality) were analysed for the presence of either of the three mutations $11043 \mathrm{~L} / \mathrm{M} / \mathrm{F}$, previously linked to DFB resistance. No mutations were detected (Fig.1, Additional file 1: Table S2). Likewise, no mutations were recorded in the 178 genotyped samples from USA, Brazil, Belize, Gabon, Switzerland, Taiwan, France, Mexico, China, Sri Lanka, Australia, Japan, Lebanon and Bangladesh (Additional file 1: Table S3).

\section{Esterase gene amplification}

CCEae3a and CCEae6a amplification associated with temephos resistance was recorded in 8 out of the 11 surveyed regions in Greece (Fig. 1). Two types of amplification were found: a CCEae3a amplicon and a CCEae3a - CCEae6a co-amplicon.

Amplified esterase genes were detected in specimens from Chios, Argolida, Patra, Kalamata, Attica, Chania, Rethymno and Heraklion. The reported frequency of the CCeae $3 a$ amplification, in the eight locations, ranged from 16.6 to $84 \%$ and that of CCEae3a-CCEae6a coamplification from 5 to $80 \%$. The majority of samples with amplified esterases harboured between 2-10 gene copies. Individuals with more than 10 (11-20) and more than 20 gene copies (in the case of one individual from Rethymno) were also recorded. Attica was the region with the highest percentage of individuals carrying $\geq$ 2 copies of either CCEae3a or CCEae6a gene (84\% and $80 \%$, respectively) and Chios of individuals with $>10$ copies (25\% and 33.3\%, respectively) (Fig. 2).

No carboxylesterase gene amplification was detected in Rodopi, Thessaloniki and Kefalonia populations.

\section{Discussion}

This study represents an extended investigation of the insecticide resistance status of Ae. albopictus in Greece. Entomological monitoring revealed the dominant presence of Ae. albopictus over other Aedes containerbreeding species and confirmed the species' widespread distribution in the country $[12,45]$. The discrimination of Ae. albopictus from morphologically similar Stegomyia species using the nuclear ITS2 as a molecular marker [35] is of high importance in order to distinguish this species from the primary arbovirus vector Ae. aegypti [46] and the non-vector Ae. cretinus [47]. The latter, although considered a native mosquito species in Greece [48] 
Table 2 WHO bioassay mortalities for Ae. albopictus populations tested against Bti

\begin{tabular}{|c|c|c|c|c|c|c|c|c|c|}
\hline \multirow[t]{2}{*}{$B+i$} & \multirow[t]{2}{*}{ Population } & \multirow[t]{2}{*}{$n$} & \multicolumn{2}{|l|}{$\mathrm{LC}_{50}(95 \% \mathrm{Cl})$} & \multicolumn{2}{|l|}{$\mathrm{LC}_{95}(95 \% \mathrm{Cl})$} & \multirow[t]{2}{*}{ Slope \pm SE } & \multirow[t]{2}{*}{$x^{2}$} & \multirow[t]{2}{*}{$d f$} \\
\hline & & & $\mathrm{mg} / \mathrm{l}$ & ITU/ml & mg/l & ITU/ml & & & \\
\hline \multirow[t]{3}{*}{1200 ITU/mg } & Patras & 250 & $\begin{array}{l}0.130 \\
(0.080-0.171)\end{array}$ & $\begin{array}{l}0.156 \\
(0.096-0.205)\end{array}$ & $\begin{array}{l}0.356 \\
(0.250-0.994)\end{array}$ & $\begin{array}{l}0.427 \\
(0.300-1.193)\end{array}$ & $3.76 \pm 0.45$ & 113.3 & 23 \\
\hline & A. Stefanos- ATT & 301 & $\begin{array}{l}0.195 \\
(0.156-0.235)\end{array}$ & $\begin{array}{l}0.234 \\
(0.187-0.282)\end{array}$ & $\begin{array}{l}0.465 \\
(0.360-0.736)\end{array}$ & $\begin{array}{l}0.547 \\
(0.432-0.883)\end{array}$ & $4.39 \pm 0.41$ & 88.59 & 28 \\
\hline & Heraklion & 243 & $\begin{array}{l}0.145 \\
(0.113-0.179)\end{array}$ & $\begin{array}{l}0.174 \\
(0.136-0.215)\end{array}$ & $\begin{array}{l}0.383 \\
(0.276-0.874)\end{array}$ & $\begin{array}{l}0.459 \\
(0.331-1.049)\end{array}$ & $3.90 \pm 0.49$ & 75.46 & 23 \\
\hline \multirow[t]{3}{*}{7000 ITU/mg } & \multicolumn{4}{|c|}{ Susceptible laboratory strains } & & & & & \\
\hline & Li et al. [39] & & $\begin{array}{l}0.036 \\
(0.028-0.047)\end{array}$ & $\begin{array}{l}0.252 \\
(0.196-0.329)\end{array}$ & & & & & \\
\hline & Su et al. [40] & & $\begin{array}{l}0.044 \\
(0.040-0.050)\end{array}$ & $\begin{array}{l}0.308 \\
(0.280-0.350)\end{array}$ & & & & & \\
\hline
\end{tabular}

Abbreviations: ATT, Attica region; $n$, total number of larvae tested to a range of insecticide concentrations; $\mathrm{LC}_{50}$, lethal concentration (mg/l) that kills $50 \%$ of the population; $\mathrm{LC}_{90}$, lethal concentration (mg/l) that kills $95 \%$ of the population, $\mathrm{Cl}$, confidence intervals; ITU, international toxic units; $X^{2}, \mathrm{Chi}$-square testing linearity of dose-mortality response with degrees of freedom ( $\mathrm{df}$ ); $d f$, degrees of freedom

Notes: Log-dose probit-mortality data for larvicides tested against Ae. albopictus larvae. The results are compared to the susceptible laboratory Ae. albopictus control strains of other studies $[39,40]$

Table 3 CDC bottle bioassay mortalities for Ae. albopictus populations tested against deltamethrin (pyrethroid) and malathion (OP)

\begin{tabular}{|c|c|c|c|c|c|c|}
\hline \multirow[t]{2}{*}{ Population } & \multicolumn{3}{|c|}{ Deltamethrin $10 \mu \mathrm{g} / \mathrm{ml}$} & \multicolumn{3}{|c|}{ Malathion $50 \mu \mathrm{g} / \mathrm{ml}$} \\
\hline & $n_{1}$ & Mortality (\%) (95\% Cl) & Status & $n_{2}$ & Mortality (\%) (95\% Cl) & Status \\
\hline A. Stefanos-ATT & 75 & $100(-)$ & S & 79 & $55.70(28.55-82.85)$ & $\mathrm{R}$ \\
\hline Patras & 70 & $100(-)$ & $\mathrm{S}$ & 83 & $91.4(83.10-99.70)$ & $\mathrm{R}^{\mathrm{a}}$ \\
\hline Kefalonia & 88 & $100(-)$ & S & 83 & $55.6(15.15-96.05)$ & $\mathrm{R}$ \\
\hline Heraklion & 78 & $100(-)$ & S & 78 & $55.3(33.70-76.90)$ & $\mathrm{R}$ \\
\hline Susceptible LC & 70 & $100(-)$ & S & 76 & $100(-)$ & $\mathrm{S}$ \\
\hline
\end{tabular}

a Possibility of resistance

Notes: Mortality percentages correspond to the discriminating exposure time DT=30 min for both insecticides [40]. The average values of four insecticide treated replicate bottles are presented. $n_{1}$ and $n_{2}$ refer to the total number of female mosquitoes tested against deltamethrin and malathion, respectively

Abbreviations: ATT, Attica region; $\mathrm{Cl}$, confidence intervals; LC, laboratory colony; R, resistance; $\mathrm{S}$, susceptibility (according to WHO recommendations for CDC bottle bioassay guidelines, 2010)

extensively reported in the past in Attica and Crete [45], was detected in our study only in Chania, Crete corresponding to an overall frequency of $2.4 \%$. The absence/ very low Ae. cretinus frequency in the sampled urban and peri- urban settings may be correlated to the competitive and highly adaptable behavior displayed by Ae. albopictus [49].

The Ae. albopictus WHO and CDC bioassays showed full susceptibility of the tested populations against deltamethrin and the larvicides DFB and Bti, suggesting their current suitability for inclusion in vector control programmes in Greece. On the contrary, mortality levels $<90 \%$ were recorded in the malathion assays indicating resistance against this OP insecticide. Although malathion and OPs are not currently used in Greece for mosquito control, OPs are still used in agriculture and thus possibly maintain a selection pressure also against
Ae. albopictus. Alternatively, the fitness cost of the $C C E$ amplification may be negligible, to allow a decrease in OP resistance. Nevertheless, the observed resistance raises some level of concern, regarding the potential need for re-introducing OP insecticides, in case of public health emergency.

Genotyping of the VGSC gene for the detection of mutations associated with pyrethroid resistance revealed a widespread distribution of the $k d r$ mutation F1534C across the country, following initial reports of the mutation in Greece $[50,51]$. The recorded $1534 \mathrm{C}$ allele frequencies were above $40 \%$ in populations from southern and central Greece, peaking in Attica (68.3\%). Previous studies also report relatively high mutation frequencies (reaching 66\%) in populations sampled from the Attica region [50, 51]. To date, $k d r$ F1534C has also been recorded in Brazil [52], Singapore, Vietnam [53] and China [54], while other substitutions in the same 
Table 4 Genotype and allele frequencies (\%) of VGSC domain II locus V1016 and domain III loci I1532 and F1534

\begin{tabular}{|c|c|c|c|c|c|c|c|c|c|c|c|c|c|c|}
\hline \multirow[t]{3}{*}{ Region } & \multirow[t]{3}{*}{ Year } & \multicolumn{2}{|c|}{ V1016G } & \multicolumn{6}{|c|}{ I1532T } & \multicolumn{5}{|c|}{ F1534C } \\
\hline & & \multirow[t]{2}{*}{$N_{1}$} & \multirow{2}{*}{$\begin{array}{l}\% \text { allele freq } \\
\text { (V) }\end{array}$} & \multirow[t]{2}{*}{$N_{2}$} & \multicolumn{3}{|c|}{ Genotype } & \multicolumn{2}{|c|}{$\%$ allele freq } & \multicolumn{3}{|c|}{ Genotype } & \multicolumn{2}{|c|}{$\%$ allele freq } \\
\hline & & & & & $\|$ & $\mathrm{IT}$ & $\mathrm{TT}$ & $(\mathrm{l})$ & $(\mathrm{T})$ & $\mathrm{FF}$ & $\mathrm{FC}$ & $\mathrm{CC}$ & $(\mathrm{F})$ & (C) \\
\hline Rodopi & 2018 & 13 & 100 & 12 & 11 & 1 & 0 & 95.8 & 4.2 & 8 & 4 & 0 & 83.3 & 16.7 \\
\hline \multicolumn{15}{|l|}{ Thessaloniki } \\
\hline Diavata, Lagkadikia ${ }^{\text {b }}$ & 2017 & $18^{a}$ & 100 & 8 & 8 & 0 & 0 & 100 & 0 & 7 & 1 & 0 & 93.8 & 6.2 \\
\hline Thermi-Litsa & 2018 & 30 & 100 & 30 & 28 & 2 & 0 & 96.7 & 3.3 & 26 & 4 & 0 & 93.3 & 6.7 \\
\hline Chios $^{b}$ & 2017 & $22^{a}$ & 100 & 11 & 11 & 0 & 0 & 100 & 0 & 6 & 4 & 1 & 72.7 & 27.3 \\
\hline Attica & 2018 & 59 & 100 & 52 & 52 & 0 & 0 & 100 & 0 & 12 & 9 & 31 & 31.7 & 68.3 \\
\hline Kefalonia & 2019 & 45 & 100 & 41 & 41 & 0 & 0 & 100 & 0 & 37 & 1 & 3 & 91.5 & 8.5 \\
\hline Patras & 2019 & 33 & 100 & 33 & 20 & 11 & 2 & 77.3 & 22.7 & 28 & 5 & 0 & 92.4 & 7.6 \\
\hline Argolida & 2018 & 21 & 100 & 21 & 19 & 2 & 0 & 95.2 & 4.8 & 10 & 3 & 8 & 54.8 & 45.2 \\
\hline Kalamata & 2018 & 7 & 100 & 6 & 6 & 0 & 0 & 100 & 0 & 2 & 3 & 1 & 58.3 & 41.7 \\
\hline Rethymno & 2018 & 20 & 100 & 30 & 29 & 1 & 0 & 98.3 & 1.7 & 10 & 11 & 9 & 51.7 & 48.3 \\
\hline Chania & 2018 & 31 & 100 & 31 & 27 & 4 & 0 & 93.5 & 6.5 & 15 & 14 & 2 & 71.0 & 29.0 \\
\hline Heraklion & 2019 & 44 & 100 & 44 & 44 & 0 & 0 & 100 & 0 & 15 & 19 & 10 & 55.7 & 44.3 \\
\hline
\end{tabular}

${ }^{a}$ Includes 10 eggs analysed in a pool. Results are presented cumulatively for the different sampling localities in each region, except for Thessaloniki bamples from Diavata and Lagkadikia refugee camps (Thessaloniki) and Chios were analysed in Fotakis et al. [33]

Abbreviations: $N_{1}$ and $N_{2}$, total number of genotyped specimens for VGSC domain II and domain III respectively, per sampling region; $V$, $1016 \mathrm{~V}$ susceptible allele. Genotypes for VGSC locus 1016 are not given as all samples were wild-type 1016V/1016V; I, 1532I susceptible allele; T, 1532T mutant allele; II, 1532I/1532I homozygous; IT, 1532I/1532T heterozygote; TT, 1532T/1532T homozygous mutant; F, 1534F susceptible allele; C, 1534C mutant allele; FF, 1534F/1534F homozygous; FC, 1534F/1534C heterozygote; CC, 1534C/1534C homozygous mutant

genomic locus, F1534L and F1534S, also associated with pyrethroid resistance, have been identified in the USA, China, Vietnam and Italy [50, 53-55].

The involvement of both F1534L and F1534S mutations in resistance to type I pyrethoids was recently further supported by in vitro functional characterization data [24]. The F1534L substitution was shown to confer similar levels of insensitivity to the previously characterized F1534C, while F1534S seemed to have an even bigger effect. Thus, monitoring the presence of these mutations in countries, like Greece, where type I pyrethroids are used for vector control is of great importance.

The F1534C mutation in the homozygous state has been associated with resistance to permethrin [23] in Aedes mosquitoes. In the analysed populations, F1534C was observed mainly in heterozygosis, potentially accounting for low resistance levels, due to the recessive nature of the mutant $1534 \mathrm{C}$ allele [56]. Nevertheless, the recorded mutation frequencies should not be undermined, as a notable raise of insecticidal pressure may lead to rapid increase in mutation selection potentially hampering the effectiveness of permethrin based applications for Ae. albopictus control. Additionally, the investigation of P450s-mediated pyrethroid detoxification, which in combination with target-site mutations has been shown to confer operationally significant resistance levels [57], would be critical complementary evidence facilitating the development of efficient control programmes.
Another mutation in the VGSC gene, I1532T, was found in Greece at low frequencies $(<10 \%)$ in several surveyed regions with the exception of Patras (western Greece) where the mutant allele reached a frequency of $22.7 \%$. This mutation has also been reported at considerable frequencies in Ae. albopictus populations from Italy [50, 51], Albania [51] and China [54]. Although Kasai et al. [53] demonstrated a lack of association between this mutation and resistance to pyrethroids, a recent study revealed that VGSC channels carrying this mutation have reduced sensitivity to type I pyrethoids, notably at similar levels to channels harbouring the F1534S mutation [24]. Therefore, it is important to monitor the presence and distribution of this mutation in field populations. We also identified in our samples two individuals carrying both the I1532T and F1534C mutations. In some cases, mutation co-occurrence can have an additive or even synergistic effect resulting in very high levels of resistance [22]. Although the co-occurrence of I1532T + F1534C has not yet been functionally characterized, the co-occurrence of I1532T with F1534S or F1534L was recently shown to have a similar effect as the single mutants in conferring type I pyrethroid insensitivity [24].

The V1016G $k d r$ mutation, correlated with "stronger" resistance (than F1534C) to type I and type II pyrethroids $[23,53]$ was not detected in any of the analysed samples from Greece. However, it was recently recorded in Ae. albopictus populations from Hanoi (Vietnam), in Beijing 


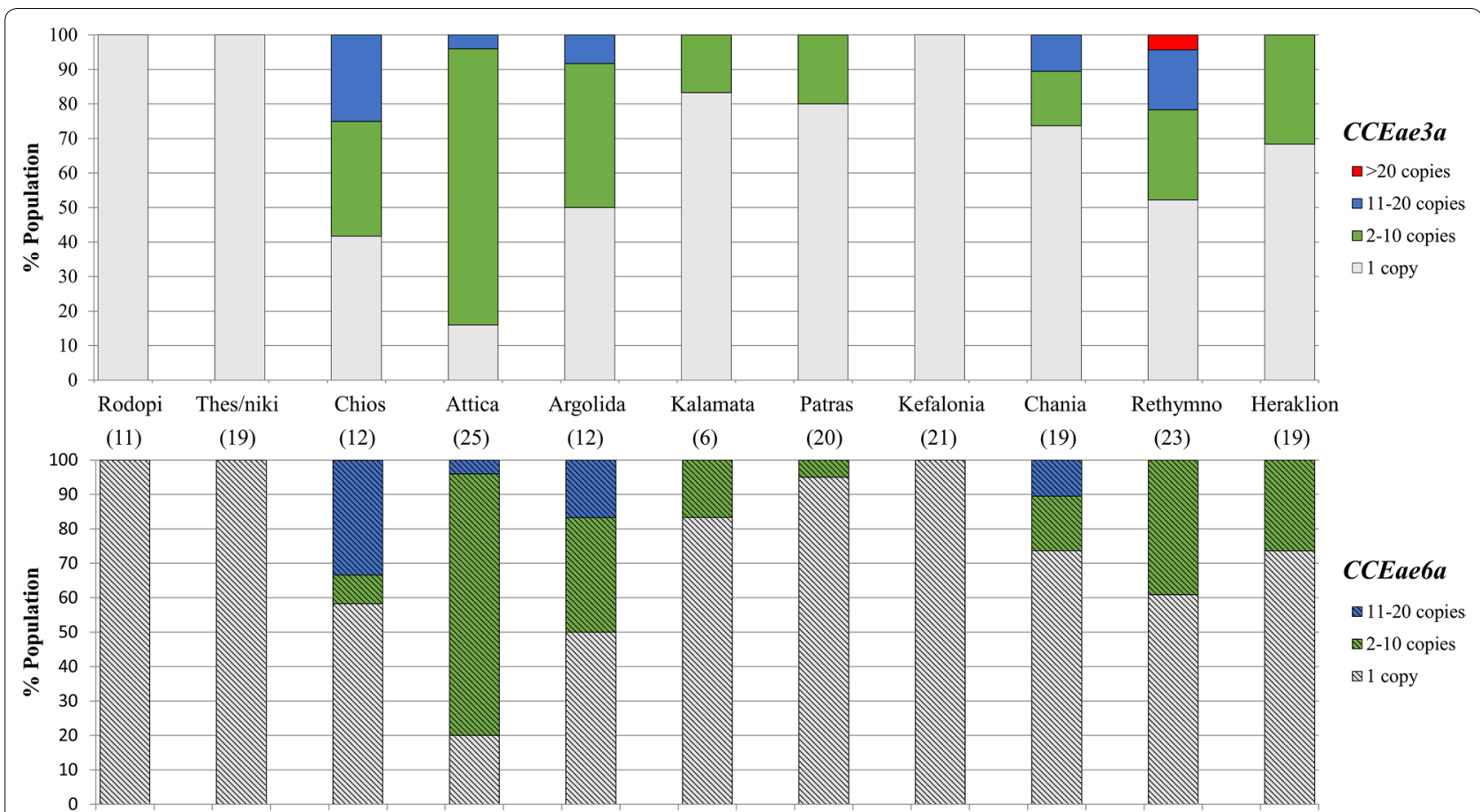

Fig. 2 Distribution of the relative CCEae3a and CCEae6a gene copy numbers in Aedes albopictus per sampling region. Solid bars (upper panel) refer to relative CCEae3a and patterned bars (lower panel) to relative CCEae6a gene copy numbers. Numbers in parentheses correspond to the number of specimens commonly analysed for both CCEs gene amplification with quantitative PCR. Results of each region presented are cumulative of different localities

(China) and across Italy $[51,53,58]$. The systematic monitoring of this mutation in Ae. albopictus populations from Greece and elsewhere is strongly recommended, given the primary role of pyrethroids in Aedes mosquito control worldwide [18] and the possibility of low mutation frequencies and/or focal mutation distribution going undetected.

Resistance to DFB was assessed molecularly in specimens from all 11 surveyed regions in Greece through monitoring of the substitutions I1043L/M/F in the CHS-1 gene, associated with high resistance levels in $C x$. pipiens mosquitoes [29-31]. No CHS-1 mutations were recorded, a result in line with the respective bioassay outcome, indicating the effectiveness of DFB for Ae. albopictus control in the study regions. Likewise, all samples analysed from France, Switzerland, Lebanon, Belize, Gabon, Taiwan, Sri Lanka, China, Japan, Australia, Bangladesh, USA, Brazil and Mexico were homozygous for the wild type (susceptible) I1043 allele, indicating that this resistance mechanism is likely not yet present in Ae. albopictus worldwide. However, the possibility of a focal DFB resistance pattern, in line with $C x$. pipiens findings [30] cannot be excluded, emphasizing the need for incorporating systematic monitoring of DFB resistance mutations in integrated Ae. albopictus surveillance programmes.
Carboxylesterase CCEae3a and CCEae6a gene amplifications linked to temephos resistance [27, 28] were detected in 8 out of the 11 surveyed regions. Almost 33\% of the total Ae. albopictus specimens analysed, the majority of which were sampled from central and southern Greece, carried more than 1 copy of CCEae $3 a$ or both CCEAe3a-CCEae6a genes indicating elevated temephos detoxification.

Interestingly out of the 156 Ae. albopictus samples commonly analysed for the detection of the F1534C $k d r$ mutation and CCEae3a amplification, 25\% were found to harbor both mutations, denoting a potential risk for multi-resistance against pyrethroid and organophosphate insecticides.

The observed resistance against malathion may be associated with the high occurrence of amplified CCEs in the analysed populations. CCEae $3 a$ and CCEae $6 a$ gene amplification was originally associated with temephos resistance in Ae. albopictus mosquitoes [27], yet Marcombe et al. [59] also correlated the presence of multiple CCEAe3a gene copies with malathion resistance in Ae. aegypti mosquitoes. Thus, it is possible that the detected CCEs amplifications in the Greek Ae. albopictus populations are responsible for the resistance levels recorded in 
the malathion bioassays, by conferring cross-resistance across additional OPs.

Evident differences were noted in the frequency of the F1534C $k d r$ mutation, between populations from Thessaloniki (northern Greece; mutant F1534C allele frequency $<7 \%$ ) and sampling locations in central and southern Greece (mutant F1534C allele frequencies > 29\%). Although we cannot exclude the scenario of the passive transportation of populations harbouring insecticide resistance mutations, these differences may also partially reflect the imposed insecticidal pressures. Similarly, in Thessaloniki CCEs gene amplification was not detected in any sample, while $26-84 \%$ of the Attica, Argolida, Chania, Rethymno and Heraklion populations had more than one CCEae $3 a$ gene copy. The surveyed regions of central and southern Greece have intense agricultural activities, where pyrethroids and OPs have been used extensively for pest control over the years, possibly contaminating nearby Ae. albopictus breeding sites and leading to the selection of the respective resistance mutations [60]. On the contrary, in Thessaloniki the majority of the specimens were sampled from an organic farm (Litsa-Thermi) where no insecticides have been applied over the last ten years possibly explaining the low $k d r$ mutation frequency and the absence of CCEs amplification.

The limited number of approved insecticides for public health purposes and the worldwide data on Ae. albopictus insecticide resistance generated to date raise concerns regarding the effectiveness and suitability of the current vector control interventions. Our findings significantly enrich the available information on Ae. albopictus insecticide resistance status. In a context of evidence-based vector control programmes, regular investigation of the species composition, population dynamics and systematic resistance monitoring encompassing both bioassays and molecular diagnostics, providing highly complementary yet not redundant information, are critical components for the development of resistance management strategies.

\section{Conclusions}

This study delineates the susceptibility profile of $A e$. albopictus populations from Greece against commonly used insecticides. Our findings suggest the suitability of the larvicides DFB and Bti and the current effectiveness of pyrethroids for Ae. albopictus control. However, the presence of high $k d r$ mutation frequencies raises concerns, given the dominant role of pyrethroids in mosquito control and the few alternative synthetic compounds available for public health purposes. The OPs malathion and temephos appear unreliable alternative insecticides for possible future re-introduction in mosquito control. Systematic monitoring of the insecticide resistance traits is imperative for the development of resistance management programmes ensuring the sustainability of the current chemical control tools.

\section{Supplementary information}

Supplementary information accompanies this paper at https://doi. org/10.1186/s13071-020-04204-0.

Additional file 1: Table S1. Primers used in this study for regular and realtime PCR. Table S2. Genotype and allele frequencies of the CHS-1 locus 1043, Greece. Table S3. Genotype and allele frequencies of the CHS-1 locus 1043, other countries.

Additional file 2: Figure S1. CDC bioassay mortality percentages corresponding to exposure time against malathion and deltamethrin for Aedes albopictus populations from Greece.

\section{Abbreviations}

Bti: Bacillus thuringiensis var. israelensis; CCE: carxoxylesterase; (E)CDC: (European) Centre for Disease Control; CHIKV: chikungunya virus; CHS-1: chitin synthase-1; Cl: confidence interval; CYP: cytochrome P450 monooxygenase; DDT: dichlorodiphenyl-trichloroethane; DENV: dengue virus; $d$ : degrees of freedom; DFB: diflubenzuron; El: emergence inhibition; GCN: gene copy number; gDNA: genomic DNA; IGR: insect growth regulator; ITS2: internal transcribed spacer 2; ITU: international toxic units; LC: lethal concentration; MBDs: mosquito-borne diseases; OP: organophosphate; PCR: polymerase chain reaction; SD: standard deviation; VBDs: vector-borne diseases; VGSC: voltage-gated sodium channel; WHO: World Health Organization; WNV: West Nile virus.

\section{Acknowledgements \\ Not applicable.}

\section{Authors' contributions}

SB conducted the majority of molecular and bioassay analyses and made substantial contributions to the conception and design of the work, analysis and interpretation of the data and manuscript preparation. EAF conducted molecular and bioassay analyses and contributed to the design of the work, interpretation of the data generated and manuscript preparation. IK made substantial contributions in the sample collection and bioassay experiments. LG contributed in the molecular analyses and manuscript preparation. SM provided samples for analysis. AC provided samples for analysis and contributed in data interpretation and manuscript revisions. JV made substantial contributions to the design of the work, interpretation of data and substantively revised the work/manuscript. All authors read and approved the final manuscript.

\section{Funding}

This work was partly supported by the General Secretariat for Research and Technology (GSRT) and the Hellenic Foundation for Research and Innovation (HFRI) in the context of the action "1st Proclamation of Scholarships from ELIDEK for PhD Candidates". Research on this topic has also received funding by the Prefecture of Crete, Greece.

Availability of data and materials

All data generated or analysed during this study are included in this published article and its additional files.

Ethics approval and consent to participate

Not applicable.

Consent for publication

Not applicable.

\section{Competing interests}

The authors declare that they have no competing interests

\section{Author details}

${ }^{1}$ Department of Crop Science, Pesticide Science Lab, Agricultural University of Athens, Athens, Greece. ${ }^{2}$ Institute of Molecular Biology and Biotechnology, 
Foundation for Research and Technology Hellas, Heraklion, Greece. ${ }^{3}$ Department of Vector Biology, Liverpool School of Tropical Medicine, Pembroke Place, Liverpool, UK. ${ }^{4}$ Bioefarmoges Eleftheriou LP -Integrated Mosquito Control, Marathon 19007, Greece. ${ }^{5}$ European Biological Control Laboratory, USDA-ARS, Thessaloniki, Greece.

Received: 2 April 2020 Accepted: 20 June 2020

Published online: 29 June 2020

\section{References}

1. Gossner MC, Ducheyne E, Schaffner F. Increased risk for autochthonous vector-borne infections transmitted by Aedes albopictus in continental Europe. Euro Surveill. 2018;23:24.

2. Barrett AD. West Nile in Europe: an increasing public health problem. J Travel Med. 2018;25(1):tay096.

3. Semenza JC. Vector-borne disease emergence and spread in the European Union. Forum on Microbial Threats; Board on Global Health; Health and Medicine Division; National Academies of Sciences, Engineering, and Medicine. Global Health Impacts of Vector-Borne Diseases: Workshop Summary. Washington: National Academies Press; 2016.

4. Kraemer MU, Sinka ME, Duda KA, Mylne AQ, Shearer FM, Barker CM, et al. The global distribution of the arbovirus vectors Aedes aegypti and $A e$. albopictus. eLife. 2015;4:e08347.

5. Paupy C, Delatte H, Bagny L, Corbel V, Fontenille D. Aedes albopictus, an arbovirus vector: From the darkness to the light. Microbes Infect. 2009;11:1177-85.

6. Adhami J, Reiter P. Introduction and establishment of Aedes (Stegomyia) albopictus Skuse (Diptera: Culicidae) in Albania. J Am Mosq Control Assoc. 1998:14:340-3.

7. ECDC. Mosquito maps. Stockholm: European Centre for Disease Prevention and Control and European Food Safety Authority; 2019. https://ecdc. europa.eu/en/disease-vectors/surveillance-and-disease-data/mosqu ito-maps. Accessed 30 Jan 2019.

8. Gratz NG. Critical review of the vector status of Aedes albopictus. Med Vet Entomol. 2004;18:215-27.

9. ECDC. Zika virus infection. Annual epidemiological report for 2016. Stockholm; European Centre for Disease Prevention and Control; 2018. https:// www.ecdc.europa.eu/sites/default/files/documents/AER_for_2016-Zikavirus-infection.pdf. Accessed 12 Oct 2018.

10. ECDC. Zika virus infection. Annual epidemiological reports for 2017. Stockholm; European Centre for Disease Prevention and Control; 2019. https://www.ecdc.europa.eu/sites/default/files/documents/AER for_2017-Zika-virus-disease.pdf. Accessed 29 Jul 2019.

11. Jupille H, Seixas G, Mousson L, Sousa CA, Failloux AB. Zika virus, a new threat for Europe? PLoS Negl Trop Dis. 2016;10:e0004901.

12. Badieritakis E, Papachristos D, Latinopoulos D, Stefopoulou A, Kolimenakis A, Bithas K, et al. Aedes albopictus (Skuse, 1895) (Diptera: Culicidae) in Greece: 13 years of living with the Asian tiger mosquito. Parasitol Res. 2018;117(2):453-60.

13. West Nile virus in Greece. Annual epidemiological report for 2018. In: National Public Health Organization. H.C.D.C.P. 2018. https://eody.gov.gr/ wp-content/uploads/2019/04/Annual_Report_WNV_2018_ENG.pdf.

14. Mavridis K, Fotakis EA, Kioulos I, Mpellou S, Konstantas S, Varela E, et al. Detection of West Nile virus - lineage 2 in Culexpipiens mosquitoes, associated with disease outbreak in Greece, 2017. Acta Trop. 2018;182:64-8.

15. Fortuna C, Remoli ME, Severini F, Di Luca M, Toma L, Bucci P, et al. Evaluation of vector competence for West Nile virus in Italian Stegomyia albopicta (=Aedes albopictus) mosquitoes. Med Vet Entomol. 2015;29:430-3.

16. Kolimenakis A, Bithas K, Latinopoulos D, Richardson C. On lifestyle trends, health and mosquitoes: formulating welfare levels for control of the Asian tiger mosquito in Greece. PLoS Negl Trop Dis. 2019;13:e0007467.

17. Wilson AL, Courtenay O, Kelly-Hope LA, Scott TW, Takken W, Torr SJ, et al. The importance of vector control for the control and elimination of vector-borne diseases. PLoS Negl Trop Dis. 2020;14:e0007831.

18. Moyes CL, Vontas J, Martins AJ, Ching Ng L, Ying Koou S, Dusfour I, et al. Contemporary status of insecticide resistance in the major Aedes vectors of arboviruses infecting humans. PLoS Negl Trop Dis. 2017;11:e0005625.
19. Bellini $\mathrm{R}$, Zeller $\mathrm{H}$, Van Bortel W. A review of the vector management methods to prevent and control outbreaks of West Nile virus infection and the challenge for Europe. Parasit Vectors. 2014;7:323.

20. Mosquito control programs, action plan and relevant information and public precaution for the year 2020. In: Ministry of Health. https://www. moh.gov.gr/. Accessed 9 Mar 2020.

21. Koliopoulos G, Kefaloudi C. Mosquitoes and their control in Greece. In: National Public Health Organization; 2018. https://eody.gov.gr/wp-conte nt/uploads/2018/12/programma_katapolemisis_kounoupiwn.pdf.

22. Liu N. Insecticide resistance in mosquitoes: impact, mechanisms, and research directions. Annu Rev Entomol. 2015;60:537-59.

23. Du Y, Nomura Y, Satar G, Hu Z, Nauen R, He SY, et al. Molecular evidence for dual pyrethroid-receptor sites on a mosquito sodium channel. Proc Natl Acad Scie USA. 2013;110:11785-90.

24. Dong K, et al. Knockdown resistance ( $k d r)$ to pyrethroid insecticides. First International Molecular Plant Protection Congress (MPPC-2019), 10-13 April 2019, Adana, Turkey.

25. Hirata K, Komagata O, Itokawa K, Yamamoto A, Tomita T, Kasai S. A single crossing-over event in voltage-sensitive $\mathrm{Na}+$ channel genes may cause critical failure of dengue mosquito control by insecticides. PLoS Negl Trop Dis. 2014;8:e3085.

26. Ishak IH, Riveron JM, Ibrahim SS, Stott R, Longbottom J, Irving H. The Cytochrome P450 gene CYP6P12 confers pyrethroid resistance in $k d r$-free Malaysian populations of the dengue vector Aedes albopictus. Sci Rep. 2016;6:24707.

27. Grigoraki L, Lagnel J, Kioulos I, Kampouraki A, Morou E, Labbé P, et al. Transcriptome profiling and genetic study reveal amplified carboxylesterase genes implicated in temephos resistance, in the Asian Tiger Mosquito Aedes albopictus. PLoS Negl Trop Dis. 2015;9:e0003771.

28. Grigoraki L, Pipini D, Labbé P, Chaskopoulou A, Weill M, Vontas J. Carboxylesterase gene amplifications associated with insecticide resistance in Aedes albopictus: geographical distribution and evolutionary origin. PLoS Negl Trop Dis. 2017;11:e0005533.

29. Grigoraki L, Puggioli A, Mavridis K, Douris V, Montanari M, Bellini R, et al. Striking difubenzuron resistance in Culex pipiens, the prime vector of West Nile Virus. Sci Rep. 2017;7:11699.

30. Porretta D, Fotakis EA, Mastrantonio V, Chaskopoulou A, Michaelakis A, Kioulos I, et al. Focal distribution of diflubenzuron resistance mutations in Culex pipiens mosquitoes from northern Italy. Acta Trop. 2019;193:106-12.

31. Fotakis EA, Mastrantonio V, Grigoraki G, Porretta D, Puggioli A, Chaskopoulou $A$, et al. Identification and detection of a novel point mutation in the chitin synthase gene of Culex pipiens associated with diflubenzuron resistance. PLoS Negl Trop Dis. 2020;14:e0008284.

32. Dusfour I, Vontas J, David JP, Weetman D, Fonseca DM, Corbel V, et al. Management of insecticide resistance in the major Aedes vectors of arboviruses: advances and challenges. PLoS Negl Trop Dis. 2019;13:e0007615.

33. Fotakis EA, Giantsis IA, Castells Sierra J, Tanti F, Balaska S, Mavridis K, et al. Population dynamics, pathogen detection and insecticide resistance of mosquito and sand fly in refugee camps, Greece. Infect Dis Poverty. 2020;9(1):30.

34. Becker N, Petric D, Zgomba M, Boase C, Madon MB, Dahl C, Kaiser A. Mosquitoes and their control. 2nd ed. New York: Springer; 2003.

35. Patsoula E, Samanidou-Voyadjoglou A, Spanakos G, Kremastinou J, Nasioulas G, Vakalis NC. Molecular and morphological characterization of Aedes albopictus in northwestern Greece and differentiation from Aedes cretinus and Aedes aegypti. J Med Entomol. 2006;43:40-54.

36. Porter C, Collins FH. Species-diagnostic differences in a ribosomal DNA internal transcribed spacer from the sibling species Anopheles freeborni and Anopheles hermsi (Diptera: Culcidae). Am J Trop Med Hyg. 1991:45:271-9.

37. WHO. Guidelines for laboratory and field testing of mosquito larvicides. Geneva: World Health Organization; 2005. https://apps.who.int/iris/handl e/10665/69101.

38. Suter T, Crespo MM, de Oliveira M, de Oliveira TS, de Melo-Santos MA, de Oliveira CM, et al. Insecticide susceptibility of Aedes albopictus and Ae. aegypti from Brazil and the Swiss-Italian border region. Parasit Vectors. 2017;10:431.

39. Li Y, Xu J, Zhong D, Zhang H, Yang W, Zhou G, et al. Evidence for multipleinsecticide resistance in urban Aedes albopictus populations in southern China. Parasit Vectors. 2018;11:4 
40. Su X, Guo Y, Deng J, Xu J, Zhou G, Zhou T, et al. Fast emerging insecticide resistance in Aedes albopictus in Guangzhou, China: alarm to the dengue epidemic. PLoS Negl Trop Dis. 2019;13:e0007665.

41. Brogdon WG, Chan A. Guidelines for evaluating insecticide resistance in vectors using the CDC bottle bioassay. CDC technical report. Methods in Anopheles research, 2nd ed. Atlanta: Centers for Disease Control and Prevention; 2010.

42. Ishak IH, Jaal Z, Ranson H, Wondji CS. Contrasting patterns of insecticide resistance and knockdown resistance $(k d r)$ in the dengue vectors Aedes aegypti and Aedes albopictus from Malaysia. Parasit Vectors. 2015;8:181.

43. Kasai S, Ng LC, Lam-Phua SG, Tang CS, Itokawa K, Komagata O, et al. First detection of a putative knockdown resistance gene in major mosquito vector, Aedes albopictus. Jpn J Infect Dis. 2011;64:217-21.

44. WHO. Guidelines for drinking-water quality 3rd edition incorporating 1st and 2nd addenda. Geneva: World Health Organization; 2008. https:// www.who.int/water_sanitation_health/dwq/fulltext.pdf.

45. Giatropoulos AK, Michaelakis AN, Koliopoulos GT, Pontikakos CM. Records of Aedes albopictus and Aedes cretinus (Diptera: Culicidae) in Greece from 2009 to 2011. Hell Plant Prot J. 2012;5:49-56.

46. Souza-Neto JA, Powell JR, Bonizzoni M. Aedes aegypti vector competence studies: a review. Infect Genet Evol. 2019;67:191-209.

47. Schaffner F, Mathis A. Dengue and dengue vectors in the WHO European region: past, present, and scenarios for the future. Lancet Infect Dis. 2014; 14:1271-80.

48. Edwards FW. A revision of the mosquitoes of the Palaearctic region. Bull Entomol Res. 1921;12:325-6.

49. Giatropoulos A, Papachristos DP, Koliopoulos G, Michaelakis A, Emmanouel N. Asymmetric mating interference between two related mosquito species: Aedes (Stegomyia) albopictus and Aedes (Stegomyia) cretinus. PLoS One. 2015;10:e0132862.

50. Xu J, Bonizzoni M, Zhong D, Zhou G, Cai S, Li Y, et al. Multi-country survey revealed prevalent and novel F1534S mutation in voltage-gated sodium channel (VGSC) gene in Aedes albopictus. PLoS Negl Trop Dis. 2016;10:e0004696.

51. Pichler $V$, Malandruccolo C, Serini P, Bellini R, Severini F, Toma L, et al. Phenotypic and genotypic pyrethroid resistance of Aedes albopictus, with focus on the 2017 chikungunya outbreak in Italy. Pest Manag Sci. 2019;75:2642-51.

52. Aguirre-Obando OA, Martins AJ, Navarro-Silva MA. First report of the Phe1534Cys $k d r$ mutation in natural populations of Aedes albopictus from Brazil. Parasit Vectors. 2017;10:160.
53. Kasai S, Caputo B, Tsunoda T, Cuong TC, Maekawa Y, Lam-Phua SG, et al. First detection of a VSSC allele V1016G conferring a high level of insecticide resistance in Aedes albopictus collected from Europe (Italy) and Asia (Vietnam), 2016: a new emerging threat to controlling arboviral diseases. Euro Surveill. 2019;24:1700847.

54. Gao JP, Chen HM, Shi H, Peng H, Ma YJ. Correlation between adult pyrethroid resistance and knockdown resistance $(k d r)$ mutations in Aedes albopictus (Diptera: Culicidae) field populations in China. Infect Dis Poverty. 2018;7:86.

55. Marcombe S, Farajollahi A, Healy SP, Clark GG, Fonseca DM. Insecticide resistance status of United States populations of Aedes albopictus and mechanisms involved. PLoS One. 2014;9:e0004696.

56. Yanola J, Somboon P, Walton C, Nachaiwieng W, Prapanthadara L. A novel F1552/C1552 point mutation in the Aedes aegypti voltage-gated sodium channel associated with permethrin resistance. Pestic Biochem Physiol. 2010;96:127-31.

57. Fadel AN, Ibrahim SS, Tchouakui M, Terence E, Wondji MJ, Tchoupo M, et al. A combination of metabolic resistance and high frequency of the $1014 \mathrm{~F} \mathrm{kdr}$ mutation is driving pyrethroid resistance in Anopheles coluzzii population from Guinea savanna of Cameroon. Parasit Vectors. 2019;12:263.

58. Zhou X, Yang C, Liu N, Li M, Tong Y, Zeng X, et al. Knockdown resistance $(k d r)$ mutations within seventeen field populations of Aedes albopictus from Beijing China: first report of a novel V1016G mutation and evolutionary origins of $k d r$ haplotypes. Parasit Vectors. 2019;12:180.

59. Marcombe S, Fustec B, Cattel J, Chonephetsarath S, Thammavong P, Phommavanh $\mathrm{N}$, et al. Distribution of insecticide resistance and mechanisms involved in the arbovirus vector Aedes aegypti in Laos and implication for vector control. PLoS Negl Trop Dis. 2019;13:e0007852.

60. Caputo B, lenco A, Cianci D, Pombi M, Petrarca V, Baseggio A, et al. The "auto-dissemination" approach: a novel concept to fight Aedes albopictus in urban areas. PLoS Negl Trop Dis. 2012;6:e1793.

\section{Publisher's Note}

Springer Nature remains neutral with regard to jurisdictional claims in published maps and institutional affiliations.
Ready to submit your research? Choose BMC and benefit from:

- fast, convenient online submission

- thorough peer review by experienced researchers in your field

- rapid publication on acceptance

- support for research data, including large and complex data types

- gold Open Access which fosters wider collaboration and increased citations

- maximum visibility for your research: over $100 \mathrm{M}$ website views per year

At BMC, research is always in progress.

Learn more biomedcentral.com/submissions 